\title{
Communication
}

[Comunicação]

\section{Topic utilization of sesquiterpene lactone from Milleria quinqueflora on treatment of bothropic envenomation in rabbits}

[Uso tópico da lactona sesquiterpênica de Milleria quinqueflora no tratamento local da pele de coelhos após envenenamento botrópico experimental]

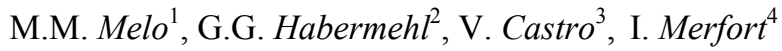 \\ ${ }^{1}$ Escola de Veterinária da UFMG \\ Caixa Postal 567 \\ 30123-970 - Belo Horizonte, MG \\ ${ }^{2}$ Chemisches Institut - Tierärztliche Hochschule - Hannover - Germany \\ ${ }^{3}$ Escuela de Quimica and CIPRONA - Universidad de Costa Rica - San José - Costa Rica \\ ${ }^{4}$ Institut für Pharmazeutische Wissenschaften - Lehrstuhl für Pharmazeutische Biologie - Freiburg - Germany
}

A prominent feature of envenomation caused by snakes of the Bothrops genus is the intense local effect, including pain, edema, hemorrhage and tissue necrosis (Barraviera and Pereira, 1994). The pathogenesis of these effects has been related to the effects of proteases, phospholipases, and hemorrhagic factors (Kamiguti et al., 1996).

The only acceptable treatment to Bothrops genus envenomation is the administration of specific anti-venom. If anti-venom administration is rapidly initiated after envenomation, neutralization of systemic effects is usually achieved. However, neutralization of local tissue damage is a more difficult task. In a number of snake bite cases, lack of neutralization of local effects results in permanent sequelae with tissue loss (Wen, 2000).

Due to the relevance of local effects in envenomation induced by snakes of the Bothrops genus, several research groups have studied this problem from different perspectives (Melo et al., 2000; Mors et al., 2000; Santos et al., 2003).

Recently, it was demonstrated that topic application of an extract from Asteraceae Milleria quinqueflora has positive effects in the treatment of local snake bite envenomation. The mainly effective secondary metabolites of this plant are sesquiterpene lactones (SL) from the germacranolide type. It was shown that they inhibit the transcription factor NF- $\kappa \mathrm{B}$ (Castro et al., 2000), a central mediator of the immune system which regulates the transcription of genes encoding various inflammatory cytokines, chemokines, adhesion molecules and inflammatory enzymes, like iNOS or COX-2 (Baeuerle and Henkel, 1994; Barnes and Karin, 1997). In general, SLs are known for their various biological, pharmacological, and especially their anti-inflammatory activities (Schmidt, 1999). Besides their NF- $\kappa$ B inhibitory activity they modulate many processes that influence inflammatory reactions, for example: oxidative phosphorylation, platelet aggregation, histamine and serotonin release (Hall et al., 1980).

In a previous study (Castro et al., 2000), it was investigated 4 $\beta, 15$-epoxy-miller-9-Z-enolide, a sesquiterpene lactone isolated from Milleria quinqueflora for its properties against the local effects of Bothrops alternatus venom in rabbits. It was used two different preparations: 95.5mgSL were diluted in $19.1 \mathrm{ml}$ of glycerol and $95.5 \mathrm{mgSL}$ were diluted in $19.1 \mathrm{ml}$ of vaseline.

Recebido para publicação em 16 de julho de 2004

Recebido para publicação em, após modificações, em 28 de dezembro 2004

E-mail: marilia@vet.ufmg.br 
Lyophilized venom of Bothrops alternatus was dissolved in sterile physiological saline $(0.85 \%$ $\mathrm{w} / \mathrm{v} \mathrm{NaCl}$ solution) and injected intradermally $(1.0 \mu \mathrm{g} / 100 \mu \mathrm{l})$ into the dorsal shaved back skin of nine New Zealand white rabbits (mean weight $800 \mathrm{~g}$ ). The rabbits were divided into three groups with three rabbits in each one: group I: $0.5 \mathrm{ml}$ of saline $(0.9 \%)$ (control); group II: $0.5 \mathrm{ml}$ of SL in glycerol $(0.5 \%)$ and group III: $0.5 \mathrm{ml}$ of SL in vaseline $(0.5 \%)$. These treatments were done topically, after venom inoculation in the following periods: 30 minutes; 1 hour, 2 hours; 4 hours; 24 hours; 30 hours; 48 hours; 54 hours, 72 hours; 96 hours, 120 hours and 148 hours.

After each treatment, a clinical evaluation of the wound diameter of the hemorrhagic halo, edema degree (pachymeter) and skin lesion (necrosis) were carried out. The animal which died was submitted to necropsy.

The effects of the SL on edema, hemorrhage and necrosis evoked by Bothrops alternatus venom are summarized on Tables 1, 2 and 3.

In accordance to the edema degree, different results in different treatments were observed.
The SL in glycerol was more effective than the SL diluted in vaseline (Table 1). In group II rabbits, $2 \mathrm{~h}$ after treatment, the edema decreased continuously and disappeared on the third day (72h). The edema values were significantly smaller than the values of groups II and III rabbits. These results indicate that the SL diluted in glycerol probably inhibits the synthesis of prostaglandin and cytokines (late phase of edema).

In group III rabbits, the effects of SLs on the rabbit edema were more pronounced in the initial inflammatory process, during the first two hours, when histamine, serotonin and kinins are the main inflammatory mediators. However, in contrast to group II rabbits, the edema increased after $4 \mathrm{~h}$ and group III rabbits showed the highest edema values after $30 \mathrm{~h}(1.03 \mathrm{~cm})$. Subsequently, edema regression occurred and disappeared totally on the $4^{\text {th }}$ day (96h), whereas in group I rabbits (control), one animal died and another showed edema until day seven (148h).

Table 1. Time course of edema development evoked by Bothrops alternatus venom, intradermally, injected after treatment of sesquiterpene lactone (SL) 4ß,15-epoxy-miller-9-Z-enolide, applied topically (mean values in centimeter) at different times

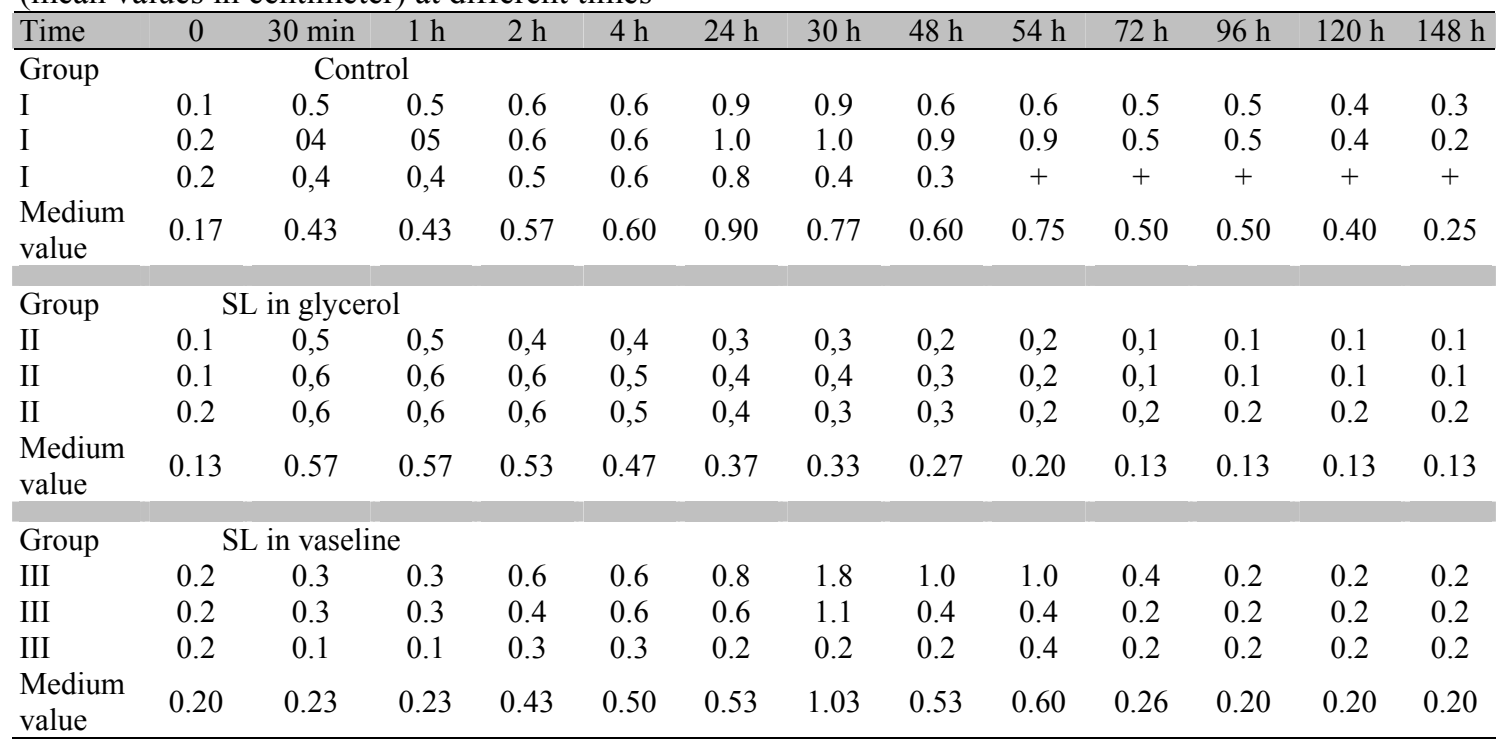

Group I: control (saline); group II: SL in glycerol; group III: SL vaseline.

+ Animal died. 
Table 2. Time course of hemorrhage development evoked by the Bothrops alternatus venom, intradermally injected, after treatment of sesquiterpene lactone (SL) 4ß,15-epoxy-miller-9-Z-enolide, applied topically (mean values in centimeter) at different times

\begin{tabular}{|c|c|c|c|c|c|c|c|c|c|c|c|c|c|}
\hline Time & 0 & $30 \mathrm{~min}$ & $1 \mathrm{~h}$ & $2 \mathrm{~h}$ & $4 \mathrm{~h}$ & $24 \mathrm{~h}$ & $30 \mathrm{~h}$ & $48 \mathrm{~h}$ & $54 \mathrm{~h}$ & $72 \mathrm{~h}$ & $96 \mathrm{~h}$ & $120 \mathrm{~h}$ & $148 \mathrm{~h}$ \\
\hline Group & & Control & & & & & & & & & & & \\
\hline I & 0 & 0.7 & 0.7 & 0.7 & 0.7 & 0.9 & 0.9 & 0.9 & 0.9 & 0.9 & 0.8 & 0.5 & 0 \\
\hline I & 0 & 0.6 & 0.6 & 0.7 & 0.7 & 2.7 & 3.2 & 1.7 & 1.7 & 1.5 & 1.1 & 1.0 & 0.7 \\
\hline I & 0 & 0.6 & 0.7 & 0.7 & 0.7 & 3.5 & 3.8 & 3.8 & + & + & + & + & + \\
\hline $\begin{array}{l}\text { Medium } \\
\text { value }\end{array}$ & 0 & 0.63 & 0.67 & 0.70 & 0.70 & 2.37 & 2.63 & 2.13 & 1.30 & 1.20 & 0.95 & 0.75 & 0.35 \\
\hline Group & \multicolumn{3}{|c|}{ SL in glycerol } & & & & & & & & & & \\
\hline II & 0 & 0.6 & 0.6 & 0,7 & 0,6 & 0,5 & 0,5 & 0 & 0 & 0 & 0 & 0 & 0 \\
\hline II & 0 & 1,2 & 1,2 & 1,2 & 0,8 & 0,6 & 0,5 & 0,5 & 0 & 0 & 0 & 0 & 0 \\
\hline II & 0 & 0,8 & 0,8 & 0,8 & 0,8 & 0,5 & 0,5 & 0,4 & 0 & 0 & 0 & 0 & 0 \\
\hline $\begin{array}{l}\text { Medium } \\
\text { value }\end{array}$ & 0 & 0.86 & 0.86 & 0.90 & 0.75 & 0.53 & 0.50 & 0.30 & 0 & 0 & 0 & 0 & 0 \\
\hline Group & \multicolumn{3}{|c|}{ SL in vaseline } & & & & & & & & & & \\
\hline III & 0 & 1.0 & 1.5 & 1.5 & 1.5 & 1.8 & 1.6 & 0.7 & 0.7 & 0.5 & 0 & 0 & 0 \\
\hline III & 0 & 0.7 & 0.7 & 0.7 & 0.7 & 0.7 & 0.6 & 0.4 & 0.4 & 0 & 0 & 0 & 0 \\
\hline III & 0 & 0.7 & 0.7 & 0.7 & 0.7 & 0.7 & 0.7 & 0.6 & 0.6 & 0 & 0 & 0 & 0 \\
\hline $\begin{array}{l}\text { Medium } \\
\text { value }\end{array}$ & 0 & 0.80 & 0.97 & 0.97 & 0.97 & 1.07 & 0.97 & 0.57 & 0.57 & 0.17 & 0 & 0 & 0 \\
\hline
\end{tabular}

Group I: control (saline); group II: SL in glycerol; group III: SL vaseline.

+ Animal died.

Table 3. Time course of necrosis development evoked by the Bothrops alternatus venom, intradermally injected, after treatment of sesquiterpene lactone (SL) 4ß,15-epoxy-miller-9-Z-enolide, applied topically (mean values in centimeter) at different times

\begin{tabular}{lccccccccccccc}
\hline Time & 0 & $30 \mathrm{~min}$ & $1 \mathrm{~h}$ & $2 \mathrm{~h}$ & $4 \mathrm{~h}$ & $24 \mathrm{~h}$ & $30 \mathrm{~h}$ & $48 \mathrm{~h}$ & $54 \mathrm{~h}$ & $72 \mathrm{~h}$ & $96 \mathrm{~h}$ & $120 \mathrm{~h}$ & $148 \mathrm{~h}$ \\
\hline Group & \multicolumn{2}{c}{ Control } & & & & & & & & & & & \\
$\mathrm{I}$ & 0 & 0 & 0 & 0 & 0 & 0.5 & 0.5 & 0.5 & 0.5 & 0.5 & 0.5 & 0.5 & 0.5 \\
$\mathrm{I}$ & 0 & 0 & 0 & 0 & 0 & 0.5 & 0.5 & 0.7 & 0.7 & 0.5 & 0.5 & 0.5 & 0.3 \\
$\mathrm{I}$ & 0 & 0 & 0 & 0 & 0 & 0.4 & 0.4 & 0.4 & + & + & + & + & + \\
Medium & 0 & 0 & 0 & 0 & 0 & 0.47 & 0.47 & 0.53 & 0.60 & 0.50 & 0.50 & 0.50 & 0.40 \\
value & & & & & & & & & & & & &
\end{tabular}



Group I: control (saline); group II: SL in glycerol; group III: SL vaseline.

+ Animal died.

*After that $48 \mathrm{~h}$, only scar (no more necrosis). 
Concerning the regression of hemorrhagic halo, group II animals showed the best results. The hemorrhagic halo totally disappeared at 54 hours in group II rabbits at 96 hours in group III rabbits, respectively. In the control group, one animal maintained the halo almost after 148 hours (Table 2).

The necrosis point appears in animals of all groups (I, II and III) at 24 hours after the inoculation of the venom. Although the SL did not prevent the necrosis, the necrosis diameter was smaller in group II rabbits than in the animals from others groups (Table 3 ). It is important to evidence that group II rabbits showed smaller values without deep skin ulceration, but it was observed scar cicatrization after $54 \mathrm{~h}$.

The following post-mortem findings were observed in one rabbit from group I: area of cutaneous ulceration (compromising of the dermis and subcutaneous tissue) outside of the inoculation venom area with intense hemorrhage (in whole back-lumbar area, deep in the muscular tissue with hemorrhagic petechiae) and edema. The heart presented flaccid ventricular walls, cyanotic with prominent vases, and coagulum in both ventricular chambers. Lungs were pink colored with the presence of subpleural petechial hemorrhage and edema. Moreover, there was petechial hemorrhage in thymus, spleen and kidneys. Spleen and intestinal loops showed flaccid consistence. The kidneys were pale with petechial hemorrhage and several retraction areas (infarct). The gross edema was possibly caused by capillary alteration and effects of proteolytic fractions from the venom. The petechial hemorrhage presence and ecchymosis in many tissues can be attributed to the toxic action of hemorragins and other fractions (Kamiguti et al., 1996).

Bothrops envenomation is very complex, presenting its effects in few minutes. The edema is produced as a consequence of the loss of the endothelial structure and by liberation of substances, such as: autacoids, histamine, kinine, prostaglandin and anafilotoxins. The hemorrhage is attributed to the metalloproteins that induce alterations in the microcirculation with increase of diapedeses. This alteration in the circulation, in addition to the local inflammation, produces ischemia and additive effects of enzymes (phospholipases $\mathrm{A}_{2}$ ) leading to myonecrosis. It is suggested that phospholipases $\mathrm{A}_{2}$ induces edema by two different mechanisms: (a) by releasing arachidonic acid as a consequence of enzymatic degradation of membrane phospholipids, enhancing the biosynthesis of eicosanoids, and (b) by directly affecting the micro vascular tissue, thereby causing plasma exsudation (Chaves et al., 1995).

Glucocorticoids that are usually given during the treatment of bothropic envenomation, are used to avoid anaphylactic reaction (after administration of the bothropic antivenom) to avoid hypovolemic shock. Glucocorticoids do not antagonize neither edema nor necrosis. Therefore, a lot of efforts are undertaken to find the best and efficient treatment capable of neutralizing the local inflammation induced by Bothrops venom.

4 $\beta, 15$-Epoxy-miller-9-Z-enolide (Fig. 1) belongs to the active constituents of Milleria quinqueflora and may be responsible for the healing effects observed during the treatment of the snake bite (Castro et al., 2000). These beneficial effects in inflammatory processes (evoked by the snake venom), may be partly due to its NF- $\kappa \mathrm{B}$ inhibitory effect, which was previously proven in in vitro studies. Further properties as already shown for other SLs, such as reduction of the phospholipase $\mathrm{A}_{2}$ activity, platelet aggregation, as well as histamine and serotonin release may also contribute to the observed healing effects (Hall et al., 1980; Schröder et al., 1990).

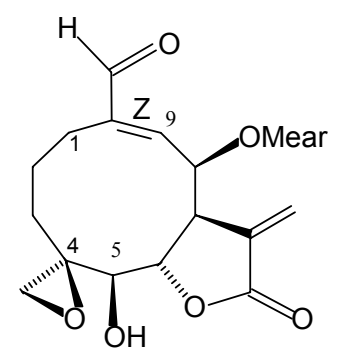

Figure 1. Structure of the investigated sesquiterpene lactone, 4 $\beta, 15$-epoxy-miller-9-Zenolide. 
Thus, this SL could be important in the treatment of local effects evoked by Bothrops venom. However, it is important to carry out further studies to determine an optimal dosage. It would also be interesting to evaluate whether other constituents of Milleria quinqueflora may have addictive effects.

Keywords: sesquiterpene lactone, bothropic envenomation, rabbit

\section{RESUMO}

Estudou-se o efeito terapêutico da lactona sesquiterpênica (SL), 4ק,15-Epoxy-miller-9-Z-enolide, na lesão local do envenenamento botrópico experimental. Utilizaram-se três grupos de coelhos inoculados com $1.0 \mu \mathrm{g}$ de veneno de Bothrops alternatus e tratados com solução $\mathrm{NaCl}$ (0,85\%) (grupo I), SL diluída em glicerol (0,5\%) (grupo II) e SL diluida em vaselina (0,5\%) (grupo III). Todos os animais foram avaliados nos tempos 30min e 1, 2, 24, 30, 48, 54, 72, 96, 120 e 148h quanto ao grau de edema, diâmetro do halo hemorrágico e presença de necrose local. Os animais do grupo II apresentaram os menores valores de grau de edema e halo hemorrágico com desaparecimento em 54h. Apesar de a necrose ter ocorrido em todos os animais, o diâmetro também foi menor no grupo II, quando comparado com os outros grupos. A SL, extraída da Milleria quinqueflora, possui efeito antiinflamatório, que é importante no tratamento local do envenenamento botrópico.

Palavras-chave: lactona sesquiterpênica, envenenamento botrópico, coelho

\section{REFERENCES}

BAEUERLE P.; HENKEL T. Function and activation of NF- $\mathrm{BB}$ in the immune system. Annu. Rev. Immunol., v.12, 141-179, 1994.

BARNES P.J.; KARIN M. Nuclear Factor-кB - A pivotal transcription factor in chronic inflammatory diseases. N. Engl. J. Med., v.336, 1066-1071, 1997.

BARRAVIERA, B.; PEREIRA, P.C.M. Acidentes por serpentes do gênero Bothrops. In: Barraviera, B. (Coord.) Venenos animais: uma visão integrada, Rio de Janeiro: Publicações Científicas, 1994. cap.19, p.261-280.

CASTRO V.; RÜNGELER P.; MURILLO R. et al. Study of sesquiterpene lactones from Milleria quinqueflora on their anti-inflammatory activity using the transcription factor NF- $\kappa \mathrm{B}$ as molecular target. Phytochemistry, v.53, 257-263, 2000.

CHAVES, F.; BARBOZA, M.; GUTIÉRREZ, J.M. Pharmacological study of edema induced by venom of snake Bothrops asper (terciopelo) in mice. Toxicon, v.33, p.31-39, 1995.

HALL, I.H.; STARNES, C.O.; LEE, K.-H. et al. Mode of action of sesquiterpene lactones as antiinflammatory agents. J. Pharmac. Sci., v.69, p.537$543,1980$.

KAMIGUTI, A.S.; HAY, C.RM.; THEAKSTON, R.D.G.et al. Review article. Insights into the mechanism of haemorrhage caused by snake venom metalloproteinases. Toxicon, v.34, p.327-642, 1996.
MELO, M.M.; HABERMEHL, G.G.; OLIVEIRA, N.J.F. Drugs against snake bite. In: SIMPÓSIO DA SOCIEDADE BRASILEIRA DE TOXINOLOGIA, 6.,2000, Águas de São Pedro, SP. 2000. Anais... Águas de São Pedro: SBTx, 2000. p.130.

MORS, W.B.; NASCIMENTO, M.C.; PEREIRA, B.M.R. et al. Plant natural products active against snake bite - the molecular approach. Phytochesmitry, v. 55 , p.627-642, 2000.

SANTOS, M.M.B.; MELO, M.M.; JACOME, D.O. et al. Avaliação das lesões locais de cães envenenados experimentalmente com Bothrops alternatus após diferentes tratamentos. Arq. Bras. Med. Vet. Zootec., v.55, p.647-649, 2003.

SCHMIDT, T.J. Toxic activities of sesquiterpene lactones: Structural and biochemical aspects. Current Org. Chem., v.3, p.577-608, 1999.

SCHRÖDER, H.; LÖSCHE, W.; STROBACH, H. et

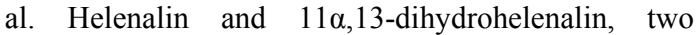
constituents from Arnica montana L. inhibit human platelet function via thiol dependent pathways. Thromb. Res., v.57, p.839-845, 1990.

WEN, F.H. Ineficácia do antiveneno na reversão do edema e necrose em pacientes picados por serpentes do gênero Bothrops. In: SIMPÓSIO DA SOCIEDADE BRASILEIRA DE TOXINOLOGIA, 6., 2000, Águas de São Pedro, SP. 2000. Anais... Águas de São Pedro: SBTx, 2000. p.78-81. 